\title{
Article
}

\section{Application of multi-based Quality Function Deployment (QFD) model to improve halal meat industry}

\author{
Vanany, Iwan, Maarif, G and Soon, Jan Mei \\ Available at http://clok.uclan.ac.uk/22478/ \\ Vanany, Iwan, Maarif, G and Soon, Jan Mei ORCID: 0000-0003-0488-1434 \\ (2019) Application of multi-based Quality Function Deployment (QFD) model \\ to improve halal meat industry. Journal of Islamic Marketing, 10 (1). pp. $97-$ \\ 124. ISSN 1759-0833
}

It is advisable to refer to the publisher's version if you intend to cite from the work. http://dx.doi.org/10.1108/IMA-10-2017-0119

For more information about UCLan's research in this area go to http://www.uclan.ac.uk/researchgroups/ and search for <name of research Group>.

For information about Research generally at UCLan please go to http://www.uclan.ac.uk/research/

All outputs in CLoK are protected by Intellectual Property Rights law, including Copyright law. Copyright, IPR and Moral Rights for the works on this site are retained by the individual authors and/or other copyright owners. Terms and conditions for use of this material are defined in the policies page.

\section{CLoK}

Central Lancashire online Knowledge www.clok.uclan.ac.uk

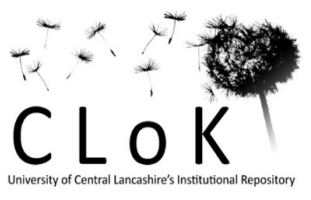




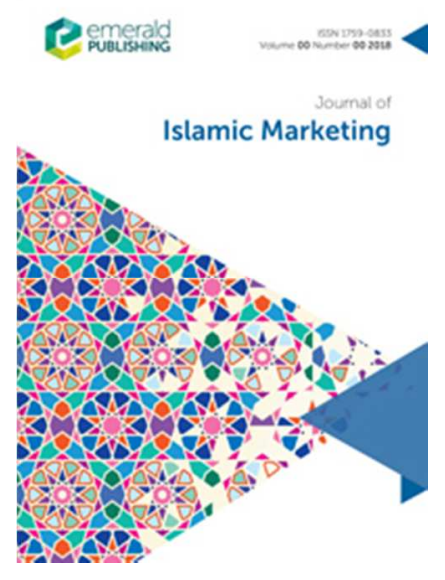

\section{Application of multi-based Quality Function Deployment (QFD) model to improve halal meat industry}

\begin{tabular}{|r|l|}
\hline Journal: & Journal of Islamic Marketing \\
\hline Manuscript ID & JIMA-10-2017-0119.R1 \\
\hline Manuscript Type: & Case Study \\
\hline Keywords: & $\begin{array}{l}\text { capacity building, critical halal factors, halal food, improvement } \\
\text { programmes }\end{array}$ \\
\hline \multicolumn{2}{|l}{} \\
\hline
\end{tabular}




\title{
Application of multi-based Quality Function Deployment (QFD) model to improve halal meat industry
}

\begin{abstract}
Purpose: Halal food market has grown significantly over the years. As consumers are becoming more aware of the significance of halal food products and certification, food industries will benefit from a model that controls and assure halal food production. Quality Function Deployment (QFD) is a tool to support product design and improving food quality systems. Thus, it is the aim of this study to propose a multi-phased QFD model to identify key processes and prioritise programmes to improve halal food production.
\end{abstract}

Methodology: The matrix in the first phase was designed using the halal assurance system (HAS) requirements and the set of production process. The relationships between HAS requirements and a set of halal critical factors (i.e. raw material (chicken), workers, procedures \& documentation, equipment, and premises) were established in the second phase. In the final phase, potential problems and improvement programmes arising under each critical halal phase were identified. The QFD model was developed and applied in a chicken processing plant in Indonesia.

Findings: In Matrix 1 - slaughtering, meat processing and meat delivery were identified as the key process whilst equipment, procedures $\&$ documentation and workers were determined as the most critical halal factors in Matrix 2. The final phase of the QFD approach assisted the chicken processing plant in reducing potential issues by identifying key improvement programmes. The prioritization of improvement programmes also supports the company in decision-making and to allocate their resources accordingly.

Practical implications: The multi-phased QFD model can be designed and adapted to specific food industry. It can be used to assure halal food production and informs food industry which area to prioritise and to allocate resources accordingly. The improvement of halal food production will assist food companies to target and access international markets.

Originality: This study proposed a new multi-phased QFD model that can be used as a halal food assurance and prioritisation tool by the food industry. This model will benefit food industry intending to implement halal assurance scheme in their process, halal auditors and policy makers.

Keywords: capacity building, critical halal factors, halal food, improvement programmes 


\section{Introduction}

In recent years, halal food is not only a part of Islamic dietary law but also represents quality, hygiene, health and cleanliness (Ambali and Bakar, 2014; Mathew et al., 2014; Soon et al., 2017) to non-Muslims. Halal food must be free from any components that Muslims are prohibited which is known as haram (not permissible) such as carrion, blood, pig, permitted animals slaughtered incorrectly, and intoxicants (Soon et al., 2017). All regulations and rules of Halal food certification which suggest that source, process and people should conform to principles of the Islamic faith (Samori et al., 2014) and also hygiene and cleanliness as part of Islamic religion (Ambali and Bakar, 2014). Halal food producers use their halal labels as a symbol of quality (Manzouri et al., 2013, Ambali and Bakar, 2014) and were combined with thoyyiban - which means "safe to consume" (Halim and Salleh, 2012). Halal food has grown significantly over the last 5 years because it is consumed not only by Muslim customers but also non-Muslim customers. Reuters and Standards (2016) reported that the halal food sector will grow approximately $18.3 \%$ of global food expenditure to US\$1,914 billion by 2021. Wilson and Liu (2010) suggested follow the "meat and money" (Halal meat and Islamic finance) as there are significant growth in the market. Globally, meat - especially poultry consumption will continue to increase (OECD-FAO, 2015). The growing population (Henchion et al., 2015), increase in incomes in developing countries (Mathijs, 2015) and urbanisation (Sans and Combris, 2015) are some of the main drivers of meat consumption. The growth in Muslim population similarly will drive the demand for halal meat.

Indonesia has a population of 255 million people where $87.2 \%$ are Muslims, representing the largest Muslim population in the world (Hefner, 2017). The average growth of Indonesian population rises approximately 3-4 million people per year. This large consumer base and potential workforce in the food industry provides promising potential in the halal food industry (Ayuniyyah et al., 2016).

Halal assurance system (HAS) is a collection of essential activities from farm to table to ensure halal compliances. HAS can help to reduce vulnerability in the food supply chain and establishes a robust halal food system through good halal control process (Vlajic et al., 2012; Tieman and Ghazali, 2014). Hazard analysis and critical control points (HACCP) based system was recommended to identify halal critical control points and potential presence of haram factors (Riaz and Chaudry, 2004; Van der Spiegel et al., 2012, Kamaruddin et al., 2012; Kohilavani et al., 2012). Riaz and Chaudry (2004) used HACCP approach to identify halal control points (HCP) at a meat slaughtering company whilst Van der Spiegel et al. (2012) determined halal critical control points in meat processing sector. Kamaruddin et al. (2012) investigated the critical control point to fulfil halal compliance along the supply chain (food processing industry, logistics providers, and local and 
international port authorities). Similarly, Kohilavani et al. (2013) explored the applicability of HACCP in Islamic dietary law while Ahmad et al. (2017) reported on critical success factors that affect halal food management systems. Dahlan et al. (2013) implemented the HAL-Q (Halal, Assurance and Liability Quality System) to ensure halal assurance in food enterprises. Understanding the vulnerability points and where preventive or corrective actions can be implemented are crucial in halal food operations. However, halal control models or approaches that can be used to identify problems, critical points and prioritise area for improvement is still limited. Reuters and Standards (2016) suggested that more frameworks or models that help the halal food industry to enhance their capability in ensuring halal compliance be conducted. Food industry and practitioners can benefit from similar tools that help to identify critical processes and prioritise areas for improvement. One such tool that could be adapted is the Quality Function Deployment (QFD) model.

QFD was first developed and implemented in Japan to support the product design process of large ships at the Kobe Shipyards of Mitsubishi Industries in 1972 (Hauser and Clausing, 1988). QFD is a customer-driven design and manufacturing tool and food industry had adapted QFD since 1987 (Costa et al., 2001; Hofmeister, 1991). With specific modifications and adaptation to meet the requirements of food industry, QFD can be valuable in the planning and designing stage of food product development (Benner et al., 2003). QFD has been used in consumer-driven food product development (Linnemann et al., 2006), fruit product development (Vatthanakul et al., 2010), organic product development (de Fatima Cardoso et al., 2015), olive oil (Bevilacqua et al., 2012) and meat product (Park et al., 2012). However, there are few published applications of QFD for the improvement of food quality systems. Previous research that utilised QFD were to increase the leanness of food supply chain (Zarei et al., 2011), implement food safety policies (Sweet et al., 2010) and improvement of production resilience in agrifood industry (Elleuch et al., 2016). Similarly, QFD can be utilised to improve halal compliance and identify areas for improvement. Halal conscious consumers are risk averse (Wilson and Liu, 2011) and values the authenticity of halal food. This was evident in a halal marketing study where respondents selected authenticity of meat being halal as the most important factor (Ahmed, 2008). With the surge in halal economy and demand for halal food, halal authenticity and verification of halal assurance play an important role in ensuring the integrity of the supply chain. QFD is a system that can assure halal compliance in food manufacturing environment. It is the aim of this study to propose a multi-phased QFD model to identify key processes and prioritise programmes to improve halal food production.

\section{Methodology}


Two research stages to develop a three-phase QFD model based on other similar QFD approaches used in food products development and innovation (Benner et al., 2003, de Fatima-Cardoso et al., 2015, and Sayadi et al., 2017) were carried out. Benner et al. (2003) first proposed their conceptual model to gather and disseminate information for product development (e.g. demanded quality). At the same time, the authors also consider the production chain actors in the food industry. Benner et al. (2003)'s matrix of information was further adapted by de Fatima-Cardoso et al. (2015) who proposed four matrices in their QFD model. Similarly, the first phase proposed in our conceptual model represents the 'demanded quality' or 'customer' requirements. Based on previous QFD studies, understanding the product requirements involved interviews (Miguel et al., 2007), surveys with consumers (Kristianto et al., 2012; Park et al., 2012) or experts' opinion (Park et al., 2012). Halal requirements were identified based on Assessment Institute for Food, Drugs and Cosmetics Indonesian Council of Ulama (AIFDC - ICU or LPPOM - MUI)'s auditors. This stage helps to translate important halal auditor's (customer) requirements (also known as 'wants' or 'whats') into important end-product control characteristics (Costa et al., 2001). Halal auditor also represents the 'customer' in our QFD project. According to ASI (1987), a customer in a QFD project can be another manufacturer, wholesaler, retailer, a regulatory body, and a consumer. The food process

requirements were identified through semi-structured interview with the quality manager. Both the halal and food processing requirements were used to develop the initial QFD model. The second research stage (i.e. case study) involved the application and testing of the QFD model in a chicken processing plant.

\section{Development of multi-phased QFD model}

This section describes the development of the 3 phases in the QFD model for halal food control. The objective of the first phase was to prioritise the production process based on the attributes of the halal assurance system (HAS). In the second phase, the objectives are to prioritize the critical halal factors and the degree of "halalness" (quality being of halal). Finally, in the third phase, the priority of improvement programmes are evaluated and the criticality degree of halal food is determined. Figure 1 illustrates the three phases and their interrelationships in the proposed multi-phase model for halal food control.

Please insert Figure 1 here

Figure 1. Interrelated multi-phase QFD model for halal food control

First phase: Halal Assurance System (HAS) requirements and Production Process 
The matrix in the first phase was designed using the halal assurance system requirements (whats) and the set of production process (of a food factory) (how). HAS requirements $\left(A_{i}\right)$ were inputted into the matrix followed by attaching relative importance weightings to each HAS requirement to establish priorities in the halal assessment. Relative importance $\left(\mathrm{W}_{\mathrm{i}}\right)$ was based interviews with two halal auditors from AIFDC - ICU. The relative importance were ranked according to Likert Scale $1-5$ where 1 = Least important and $5=$ Most important. The production process $\left(\mathrm{H}_{\mathrm{ij}}\right)$ represents the requirements that should address each HAS attribute. Our production process also takes the supplychain operations reference (SCOR) model to evaluate the food production performance. According to SCOR, a company's supply chain is represented by 4 level of processes: plan, source, production/make and delivery (Chae, 2009). The production process was evaluated subjectively using the following scale: 9 = 'strong', 3 = 'weak', 1 = 'weak' and blank = 'non-existent' (Akao, 1990). The score $\left(S_{i j}\right)$ is calculated by multiplying the relative importance weightage $\left(W_{i}\right)$ and the production process $\left(\mathrm{H}_{\mathrm{ij}}\right)$. The summation of scores under each process determines the absolute and percent importance. This will allow the food production to identify the priority of their production process (Table 1).

Please insert Table 1 here

Table 1. Proposed first phase in matrix 1: The attributes of Halal Assurance System and Production Process Requirements

\section{Second phase: Halal Assurance System (HAS) requirements and Critical Halal Factors}

The relationships between HAS requirements (what) and a set of halal critical factors (how) were established. The halal critical factors $\left(C_{i j}\right)$ were derived from Latif et al. (2014) i.e. company profile, premises, worker, equipment, raw material, packaging \& labelling, logistic, supplier, procedures \& documentation. Halal critical factors were evaluated subjectively based on the following scale: $9=$ 'strong', 3 = 'moderate', 1 = 'weak' and blank = 'non-existent'. The score $\left(S_{\mathrm{ij}}\right)$ is calculated by multiplying the relative importance weightage $\left(W_{i}\right)$ of HAS and halal critical factors $\left(C_{i j}\right)$ followed by the determination of the absolute importance, percent importance and priority of the halal critical factors. The value of "halalness" was estimated from the total sum of the critical halal factors (Table 2).

Please insert Table 2 here

Table 2. Proposed second phase in matrix 2: The attributes of Halal Assurance System and Critical Halal Factors 


\section{Third phase: Critical Halal Factors and Improvement Programmes}

The relationships between the potential problems of the halal critical factors (what) and the improvement programmes $\left(E_{i j}\right)$ (how) were established in matrix 3 . Potential problems $\left(F_{\text {in }}\right)$ were identified (based on interview with quality manager) under each halal critical factors followed by the required improvement programmes. Relative importance for each critical factor $\left(W_{i}\right)$ and potential problem $\left(W_{\text {in }}\right)$ were based on the quality manager's input. The improvement programmes were rated based on the scale of: $9=$ 'strong', 3 = 'weak', 1 = 'weak' and blank = 'non-existent'. The score $\left(S_{i j}\right)$ is calculated by multiplying the improvement programmes $\left(E_{i j}\right)$ with the relative importance weightage $\left(W_{i}\right)$ of the halal critical factors. Similarly, the sum of absolute and percentage importance were calculated followed by ranking of priority of the improvement programmes. The degree of halal criticality for each potential problems can also be identified to support decision making in halal food control process (Table 3).

Please insert Table 3 here

Table 3. Proposed third phase in matrix 3: Critical halal factors and improvement programmes

\section{Results}

Case study: Application of multi-phase QFD model in a chicken meat processing plant

The QFD model for halal food control was applied in an Indonesian chicken meat processing company based in Jawa. The company currently employs more than 500 employees and is categorised as a large enterprise. Badan Pusat Statistik (Central Statistical Agency) defines an enterprise based on the number of workers i.e. small (5 - 19 workers), medium enterprises (20 - 99 workers) and large enterprises (more than 100 workers) (BPS, 2017; Tambunan et al., 2009). Other studies such as Sayadi et al. (2017) and Dewa et al. (2017) had similarly tested and applied their QFD models in a food environment whilst Chan and Wu (2005) illustrated their QFD model using a stepby-step approach to improve a food product. The company has three food certifications including veterinary control, the Hazard Analysis and Critical Control Points (HACCP) as the food safety certification, and halal certification. The production capacity is approximately 8000 chicken per day or $9000 \mathrm{~kg}$ per day and is equipped with cold storage, air blast freezer (ABF) and chilling room facilities. The main products (chicken carcass, breast, whole thighs, wing, boneless meat, and other chicken-based products) are distributed to customers in several Indonesian provinces.

\section{First Phase}


Two halal auditors from AIFDC - ICU and the chicken processing company quality manager provided their input in the Halal Assurance System (HAS) requirements. The researchers also observed relevant documents from the company such as the halal report from the auditors, company profile, meat processing flows and standard operating procedures (SOPs). Thirty attributes of HAS relevant to the chicken meat processing company were identified (Table 4). Relative importance for each attribute were assigned based on interviews with two halal auditors from AIFDC - ICU. For example both auditors agreed that $A_{1}$ (stress free living chicken) should be rated as 5 (very important) or $3.65 \%$ under the attributes of HAS. This ties in with Omar and Jaafar (2011) where halal supply chain starts at the farm level. This is to ensure that halal not only applies to food manufacturing plant but also for all the activities carried out prior to and after processing. Animal welfare is key in halal food supply chain, hence raising and slaughtering of animals for food must be carried out respectfully (Farouk et al., 2014) and (Farouk et al., 2016). In order to complete the process requirement, the three main supply chain processes (i.e. source, production/make, delivery) of SCOR were used. This study focus on the operational stage (source, production/make, delivery) where daily operational output and evaluations were used as the basis for future planning. Matrix 3 which identifies key improvement programmes are fed back into planning, sourcing, production systems and delivery. The researchers mapped the process from sourcing i.e. receipt of chicken from poultry farm (source), processing i.e. pre-slaughtering, slaughtering, meat processing, washing, grading and packaging, storage (make/production) and distribution of finished products (delivery).

Meanwhile, the quality manager assessed the relationships between HAS and production requirements using the following scale: 9 = 'strong', 3 = 'weak', 1 =' 'weak' and blank = 'non-existent'. For example, a value of 9 was provided under the category of $A_{1}$ (Stress-free living chicken) in HAS and the receipt of chicken from poultry farm. The quality manager indicates that stress-free living chicken would have a high impact on the quality of animal welfare. Raw materials are critical as halal integrity starts at the farm level. Good animal welfare contributes to stress-free living chickens. Islam advocates the merciful treatment of animals. Therefore, animals must be treated in a way that they are not stressed or excited prior to slaughter (Regenstein and Grandin, 2002). Animal welfare was identified as a critical control point in Bonne and Verbeke (2008). The grey cells in the matrix indicate null relationship between the HAS and production process requirements. For example, $A_{1}$ (stress-free living chicken) has no relationship or does not affect other production processes such as washing, grading and packaging, storage and delivery. In the final step, the absolute and percent importance were calculated and the rank of priority was determined. Based on the scores, slaughtering (5.83/25.32\%) and meat processing (4.34/18.86\%) were ranked as the top two priorities 
and would have the highest impact on the attributes of HAS requirements. The results show slaughtering and meat processing as critical processes and affects the quality of halal food production, hence the need to prioritise these stages in the chicken processing company.

Please insert Table 4 here

Table 4 Application of first phase of QFD model in chicken processing plant

\section{Second phase}

Similar HAS attributes were used in the second phase. From the nine critical halal factors developed by Latif et al. (2014), the halal auditors and quality manager reported that 5 of the halal critical factors were relevant in the chicken meat processing industry i.e. raw material (chicken), workers, procedures \& documentation, equipment, and premises. Similar relative importance weightage of HAS from Table 4 is used in Table 5. The relationships between the attributes of HAS requirement and the factors of the halal critical were assessed with a scale of 0,1, 3 and 9 by the quality manager and verified by the halal auditors. The total score for each attribute of the HAS requirements in the case study represent the degree of "halalness". For example, under A11 (segregated slaughterhouse for halal chicken meat) and A23 (minimal time between slaughtering and next process $=40$ seconds), both attributes summed up to 0.44 . Both attributes represent the degree of "halalness" in the chicken processing plant. The absolute and percent importance were calculated and priorities ranked accordingly. Tools (1.5/31.67\%) and staff (human) (1.12/22.43\%) and documentation $(1.12 / 22.43 \%)$ are the top three critical halal factors (Table 5).

Please insert Table 5 here

Table 5 Application of second phase of QFD model in chicken processing plant

\section{Third phase}

Potential problems arising under each critical halal phase were identified in the final phase of the QFD model. Improvement programmes relevant to the critical halal factors were included. The improvement programmes were adapted from Ahmad et al. (2017) and include supplier management, policy and procedures, and information and employee capability. Further discussion with the quality manager revealed specific improvement programmes under each theme. For example, appointment of halal supervisor and adding halal certification requirement as a supplier pre-requisite in the supplier management programme. Six specific halal improvement programmes were identified and their effectiveness were scored by the quality manager. A scale of $0,1,3$ and 9 
were used. For example, the relationship between potential problem (e.g. stressful chicken) and specific improvement programme (e.g. adding halal supervisor) was judged as 3 . The problems in the halal critical factors were multiplied with the specific improvement programmes. The total score for each problem reflect the degree of criticality. For example, C02 (lack of awareness of chicken supplier regarding halal requirements) summed up to 2.55 whilst T01 (absence of timekeeping tool) summed up to 2.55 and 1.98 respectively. The final step was to rank the priority of the improvement programmes based on the absolute and percent importance. Improving employees' capability (4.25/29.22\%), revising Standard Operating Procedures (SOPs) (2.94/20.26\%) and adding halal policy $(2.66 / 18.31 \%)$ were the top three improvement programmes that are critical to the chicken processing plant.

Insert Table 6 here

Table 6 Application of third phase of QFD model in chicken processing plant

\section{Discussion}

Broiler consumption in Indonesia was $8 \mathrm{~kg}$ per capita while egg consumption was 100 eggs per year in 2013 (Nurtini et al., 2017). The large and increasing population in Indonesia provides a continuous demand for safe and halal food products. Similarly, at the global level, the global poultry market for both halal and mainstream (non-halal) produce (live, chilled, frozen and processed products) was worth US\$ 31.1 billion in 2014 (International Trade Centre, 2015). Developing and applying a multiphase QFD model in a chicken processing company will help to ensure that halal assurance requirements are fulfilled according to the production process. This ties in with Matrix 1 (HAS $x$ Production process) which allows the chicken processor to identify which process to prioritise. Based on Table 4, slaughtering was identified as the top priority in the company. Slaughtering process represents 24 out of 30 attributes. Halal auditors and the quality manager ranked 11 attributes as very important. We can further categorise the 11 attributes into procedures (e.g. A7, A8, A13, A14, $A 19, A 20, A 22$ and A23) and facilities (A11, A12 and A25). Procedures such as usage of sharp tools, invocation, and severing minimum of 3 vessels are practiced as sharp tools can quickly sever a minimum of three out of four vessels in the neck and should only be done once (Al-Qaradawi, 1994). The knife used must be razor sharp and free of nicks so that the animal does not feel the pain of the cut. The use of an insufficiently sharp or dull knife results in an increase in force applied by the operator to severe the required vessels (Bishu et al., 1996; Marsot et al., 2007). Pronouncement is important in order to obtain permission from God before taking the life of another creature (AlQaradawi, 1994). The slaughtering process is a crucial stage as differentiation between halal and 
non-halal meat occurs at this point (Bergeaud-Blackler, 2007). According to Lever and Miele (2012), the practice of religious slaughter in this case addresses the qualification of halal and is comparable to other credence attributes that refer to the method of production rather than the intrinsic characteristics of the product. Halal is a credence quality attribute as its product characteristic cannot be evaluated by individual consumer during or even after consumption (Bonne and Verbeke, 2008; Grunert, 2005). Designated facilities for halal products should be in place to separate halal and non-halal products at all stages of processing, storage and delivery to other locations. Meat processing and delivery were ranked as the second and third priority respectively in the chicken processing plant. Most of the highly scored attributes under meat processing were associated with evidence of halal certification, free from contamination and segregation. During processing, it is crucial that the production line is free from haram foods and ingredients and food processors are recommended to use dedicated equipment and utensils (Chaudry and Riaz, 2014). Delivery plays a crucial role in ensuring that the raw materials, ingredients, packaging materials, storage and transportation of halal products are intact and not contaminated along the supply chain (Zailani et al., 2017).

Matrix 2 represents the relationship between HAS and critical halal factors. Equipment, documentation \& procedures and workers were identified as the top three critical halal factors. Tools that are critical to halal requirements include the stunning equipment and knife. According to MS1500: 2004, 2009, stunning equipment must be handled by a trained Muslim slaughterman. The stunning equipment used to stun pigs must never be used to stun animals for halal slaughter. Knives must be razor sharp so the animal does not feel pain during slaughter (Grandin, 2010). Procedures and documentation provide written description on how processing, monitoring, cleaning and control measures were carried out. According to Stier (2014), "If it is not written down, it never happened". This is especially crucial within the food industry as evidence of documentation and record keeping helps the food processor to demonstrate that the chicken products are manufactured in a safe and halal manner. Good documentation practices is a requirement in the CAC/RCP 1-1969 requirement where appropriate records of processing, production and distribution should be kept and retained for a period that exceeds the shelf life of the product (CAC, 2003). Similarly, the procedures and documentation requirement by the Assessment Institute for Food, Drugs and Cosmetics Indonesian Council of Ulama stated processors must have written procedures on the implementation of critical activities that may affect the halal status of the product (LPPOM MUI, 2014). Critical activities in the chicken processing plant are reflected in Matrix 1 where slaughtering, meat processing and meat deliveries were identified as the priorities in the production process. 


\section{Conclusion}

The demand for halal food in Indonesia is huge and provides a lucrative market nationally and globally. Halal food production requires safety, quality and wholesomeness from farm to fork. This case study proposed a multi-phase QFD approach to identify key production processes, critical halal factors and improvement programmes. In Matrix 1 - slaughtering, meat processing and meat delivery were identified as the key process whilst equipment, procedures \& documentation and workers were determined as the most critical halal factors in Matrix 2. The final phase of the QFD approach assisted the chicken processing plant in reducing potential issues by identifying key improvement programmes. The prioritization of improvement programmes also supports the 
company in decision-making and to allocate their resources accordingly. Improving employees' capacity via training and education will benefit the chicken processing plant particularly in enhancing operational performance, food safety and the importance of halal credence quality. The proposed QFD model has successfully identified key processes and halal critical factors and prioritised improvement programmes.

\section{Limitations}

The multi-phased QFD model was tailored specifically to 'customers' (halal auditors) and the chicken processing plant's requirements. As such, the processes will differ across food processors and the QFD model should be re-designed to adapt to their specific requirements. Interviews between researchers and the halal auditors and quality managers are necessary to rate the importance of each attribute and processes. As a result, food industry personnel may not have sufficient time to contribute significantly during the planning and designing of the QFD model. There should be further research and testing of the QFD model in other halal food industry such as beef and lamb industry or processed foods such as canned meat products.

\section{References}

Ab Talib, M. S., Abdul Hamid, A. B. and Thoo, A. C. (2016), "Can halal certification influence logistics performance?” Journal of Islamic Marketing, Vol. 7 No. 4, pp. 461-475.

Ahmad, A. N., Rahman, R. A., Othman, M. and Zainal Abidin, U. F. U. (2017), "Critical success factors affecting the implementation of halal food management systems: Perspective of halal executives, consultants and auditors", Food Control, Vol. 74, pp. 70-78.

Ahmed, A. (2008), "Marketing of halal meat in the United Kingdom - supermarkets versus local shops", British Food Journal, Vol. 110 No. 7, pp. 655-670.

Akao, Y. (1990). Quality function deployment: Integrating customer requirements into product design. Productivity Press, Cambridge, MA.

Ali, M. H., Tan, K. H. and Ismail, M. D. (2017), "A supply chain integrity framework for halal food", British Food Journal, Vol. 119 No. 1, pp. 20-38.

Al-Qaradawi, Y. (1994). The lawful and the prohibited in Islam. Trans: Ahmad Zaki Hammad. Indianapolis: American Trust Publications.

Ambali, A. R. and Bakar, A. N. (2014), “People's Awareness on Halal Foods and Products: Potential Issues for Policy-makers", Procedia - Social and Behavioral Sciences, Vol. 121, pp. 3-25.

ASI, American Supplier Institute (1987). Quality function deployment. American Supplier Institute, Dearborn, MI. 
Ayuniyyah, Q., Hafidhuddin, D. and Hambari, H. (2016), "Factors affecting consumers' decision in purchasing MUI halal-certified food products", Tazkia Islamic Finance and Business Review, Vol. 10 No. 2, pp. 122-143.

Benner, M., Linnemann, A. R., Jongen, W. M. F. and Folstar, P. (2003), "Quality function deployment (QFD) - can it be used to develop food products?" Food Quality and Preference, Vol. 14, pp. 327-339.

Bergeaud-Blackler, F. (2007), "New challenges for Islamic ritual slaughter: A European perspective", Journal of Ethnic and Migration Studies, Vol. 33 No. 6, pp. 965-980.

Bevilacqua, M., Ciarapica, F. E. and Marchetti, B. (2012), "Development and test of a new fuzzy-QFD approach for characterizing customers rating of extra virgin olive oil", Food Quality and Preference, Vol. 24 No. 1, pp. 75-84.

Bishu, R. R., Calkins, C., Lei, X. and Chin, A. (1996), "Effect of knife type and sharpness on cutting forces", Advances in Occupational Ergonomics and Safety, Vol. 2, pp. 479-483.

Bohari, A. M., Chen, W. H. and Fuad, N. (2013), "The competitiveness of halal food industry in Malaysia: ICT analysis", Geographia-Malaysian Journal of Society and Space, Vol. 9 No. 1, pp. 1-9.

Bonne, K. and Verbeke, W. (2008), "Religious values informing halal meat production and the control and delivery of halal credence quality", Agriculture and Human Values, Vol. 25, pp. 35-47.

BPS (2017), "Industri besar", Available at: https://www.bps.go.id/index.php/istilah/145 [Accessed 17 October 2017]

CAC, Codex Alimentarius Commission (2003). CAC/RCP 1-1969 general principles of food hygiene.

Chae, B. (2009), "Developing key performance indicators for supply chain: an industry perspective", Supply Chain Management: An International Journal, Vol. 14 No. 6, pp. 422-428.

Chan, L.-K. and Wu, M.-L. (2005), "A systematic approach to quality function deployment with a full illustrative example", Omega, Vol. 33, pp. 119-139.

Chaudry, M. N. and Riaz, M. N. (2014), "Halal food requirements", in, Encyclopedia of Food Safety, Volume 1. Y. Motarjemi, G. Moy and E. Todd (Eds.). San Diego, CA: Academic Press, pp. 486-491.

Che Hashim, H. I. and Mohd Shariff, S. M. (2016), "Halal supply chain management training: Issues and challenges", Procedia Economics and Finance, Vol. 37, pp. 33-38.

Costa, A. I. A., Dekker, M. and Jongen, W. M. F. (2001), "Quality function deployment in the food industry: a review", Trends in Food Science and Technology, Vol. 11, pp. 306-314.

Dahlan, W., Ariyapitipun, T., Sirikwanpong, S., Kunakom, B. S., Denyinghot, A. and Nopponpunth, V. (2013), "Multi-approach management for halal security in HACCP compliant seafood enterprises in Thailand", Middle East Journal of Scientific Research, Vol. 13 No. 4, pp. 464-471.

de Fátima Cardoso, J., Casarotto Filho, N. and Miguel, P. A. C. (2015), "Application of Quality Function Deployment for the development of an organic product", Food Quality and Preference, Vol. 40, pp. $180-190$. 
Dewa, P. K., Pujawan, I. N. and Vanany, I. (2017), "Human errors in warehouse operations: an improvement model", International Journal of Logistics Systems and Management, Vol. 27 No. 3, pp. 298-317.

Elleuch, H., Dafaoui, E., El Mhamedi, A. and Chabchoub, H. (2016), "A quality function deployment approach for production resilience improvement in supply chain: Case of agrifood industry", IFACPapers Online, Vol. 49-31, pp. 125-130.

Farouk, M. M., Al-Mazeedi, H. M., Sabow, A. B., Bekhit, A. E. D., Adeyemi, K. D., Sazili, A. Q. and Ghani, A. (2014), "Halal and kosher slaughter methods and meat quality: A review", Meat Science Vol. 98 No. 3, pp. 505-519.

Farouk, M. M., Pufpaff, K. M. and Amir, M. (2016), "Industrial halal meat production and animal welfare: A review”, Meat Science, Vol. 120, pp. 60-70.

Grandin T. (2010), "Discussion of research that shows that Kosher or Halal slaughter without stunning causes pain", Available from:

http://www.grandin.com/ritual/slaughter.without.stunning.causes.pain.html [Accessed 12 October 2017].

Grunert, K. G. (2005), "Food quality and safety: Consumer perception and demand", European Review of Agricultural Economics, Vol. 32, pp. 369-391.

Halim, M. A. A. and Salleh, M. M. (2012), "The possibility of uniformity on halal standards in organization of Islamic countries (OIC) country", World Applied Sciences Journal, Vol. 17 No. 17, pp. 6-10.

Hauser, J. R. and Clausing, D. (1988), "The house of quality", Harvard Business Review, pp. 63-73.

Hefner, R. W. (2017), "Christians, conflict and citizenship in Muslim majority Indonesia", The Review of Faith and International Affairs, Vol. 15 No. 1, pp. 91-101.

Henchion, M., McCarthy, M., Resconi, V. C. and Troy, D. (2014), "Meat consumption: Trends and quality matters", Meat Science, Vol. 98 No. 3, pp. 561-568.

Hofmeister, K. R. (1991). Quality function deployment: Market success through customer-driven products. In, Food Product Development: From Concept to the Marketplace. E. Graf and I. S. Saguy (Eds.). New York: Van Nostrand and Reinhold, pp. 189-210.

International Trade Centre (2015), "From niche to mainstream. Halal goes global", Available at: http://www.intracen.org/publication/From-niche-to-mainstream---Halal-Goes-Global/ [Accessed 15 October 2017].

Kamaruddin, R., Iberahim, H. and Shabudin, A. (2012), "Halal compliance critical control point (HCCCP) analysis of processed food", IEEE Business, Engineering \& Industrial Applications Colloquium (BEIAC), pp. 383-387.

Kohilavani, Yang, T. A., Febrianto, N. A., Abdullah, W. and Tajul Aris, A. (2012), “A decision tree based approach for the identification of Halal Critical Control Points for slaughtering according to Islamic dietary law", Internet Journal of Food Safety, Vol. 14, 48-53.

Kohilavani, Zzaman, W., Febrianto, N., Zakariya, N., Abdullah, W. and Yang, T. (2013), “Embedding Islamic dietary requirements into HACCP approach", Food Control, Vol. 34 No. 2, 607-612. 
Kristianto, Y., Ajmal, M. M., and Sandhu, M. (2012), “Adopting TQM approach to achieve customer satisfaction: A flour milling company case study", TQM Journal, Vol. 24 No. 1, pp. 29-46.

Latif, I. A., Mohamed, Z., Sharifuddin, J., Abdullah, A. M. and Ismail, M. M. (2014), "A comparative analysis of global halal certification requirements", Journal of Food Products Marketing, Vol. 20, pp. 85-101.

Lever, J. and Miele, M. (2012), "The growth of halal meat markets in Europe: An exploration of the supply side theory of religion", Journal of Rural Studies, Vol. 28, pp. 528-537.

Linnemann, A. R., Benner, M., Verkerk, R. and van Boekel, M. A. J. S. (2006), “Consumer-driven food product development", Trends in Food Science and Technology, Vol. 17, pp. 184-190.

LPPOM MUI, Lembaga Pengkajian Pangan Obat obatan dan Komestika Majelis Ulama Indonesia (2014), "Persyaratan sertifikasi halal MUI", Available at: http://www.halalmui.org/mui14/index.php/main/go_to_section/58/1366/page/1 [Accessed 13 October 2017].

Manzouri, M., Nizam Ab Rahman, M., Saibani, N., \& Rosmawati Che Mohd Zain, C. (2013), "Lean supply chain practices in the Halal food", International Journal of Lean Six Sigma, Vol. 4 No. 4, pp. 389-408.

Marsot, J., Claudon, L. and Jacqmin, M. (2007), “Assessment of knife sharpness by means of a cutting force measuring system", Applied Ergonomics, Vol. 38, pp. 83-89.

Mathew, V. N., Abdullah, A. M. R. B. A. and Ismail, S. N. B. M. (2014), "Acceptance on halal food among non-Muslim consumers", Procedia - Social and Behavioral Sciences, Vol. 121, pp. 262-271.

Mathijs, E. (2015), “Exploring future patterns of meat consumption", Meat Science, Vol. 109, pp. 112-116.

Miguel, A. C. A., Spoto, M. H. F., Abrahao, C. and da Silva, P. P. M. (2007), "Consumer profile evaluation by quality function deployment for a pineapple", Ciencia e Agrotecnologia, Vol. 31 No. 2, pp. 563-569.

MS 1500: 2004 (Malaysian Standard) (2004), “Halal food - Production, preparation, handling and storage - General guidelines", First Revision. Department of Standards Malaysia. Available from: https://firatozel.files.wordpress.com/2011/08/halal-food-malaysian-standard.pdf. [Accessed 13 October 2017].

MS 1500: 2009 (Malaysian Standard) (2009), "Halal food - Production, preparation, handling and storage - General guidelines. Second Revision. Department of Standards Malaysia", Available from: https://law.resource.org/pub/my/ibr/ms.1500.2009.pdf [Accessed 13 October 2017].

Murphy, K. S., DiPietro, R. B., Kock, G. and Lee, J. (2011), “Does mandatory food safety training and certification for restaurant employees improve inspection outcomes?" International Journal of Hospitality Management, Vol. 30 No. 1, pp. 150-156.

Nurtini, S., Mujtahidah, A. U., Muzayyanah, F., Haryadi, T. and Abdul Hakim (2017), "Performance of broiler farmer in partnerships system at Surakarta, Indonesia", Journal of Advanced Agricultural Technologies, Vol. 4 No. 2, pp. 196-199. 
OECD-FAO (2015), "OECD-FAO Agricultural Outlook 2016-2025", Available at: http://www.oecdilibrary.org/agriculture-and-food/oecd-fao-agricultural-outlook-2016-2025/world-meatprojections agr outlook-2016-table102-en [Accessed 23 April 2018].

Omar, E. N. and Jaafar, H. S. (2011), "Halal supply chain in the food industry - A conceptual model", Business, Engineering and Industrial Applications (ISBEIA). 2011 IEEE Symposium, pp. 384-389.

Park, S.-H., Ham, S. and Lee, M.-A. (2012), "How to improve the promotion of Korean beef barbeque, bulgogi, for international customers: An application of quality function deployment", Appetite, Vol. 59 No. 2, pp. 324-332.

Prabowo, S., Abd Rahman, A., Ab Rahman, S. and Abu Samah, A. (2015), "Revealing factors hindering halal certification in East Kalimantan Indonesia", Journal of Islamic Marketing, Vol. 6 No. 2, pp. 268291.

Reuters, T. and Standards, D. (2016). State of the global Islamic economy report 2016/17. United Arab Emirates Dubai.

Regenstein, J. M. and Grandin, T. (2002), "Animal welfare: kosher and halal”, IFT Religious and Ethnic Foods Division Newsletter, Vol. 5, pp. 2.

Riaz, M. N., and Chaudry, M. M. (2004). Halal food production. CRC Press, LCC., Boca Raton, FL, USA.

Samori, Z., Ishak, A. H. and Kassan, N. H. (2014), "Understanding the development of halal food standard: suggestion for future research", International Journal of Social Science and Humanity, Vol. 4 No. 6, pp. 482-486.

Sans, P. and Combris, P. (2015), "World meat consumption patterns: An overview of the last fifty years (1961 - 2011)", Meat Science, Vol. 109, pp. 106-111.

Sayadi, S., Erraach, Y. and Parra-López, C. (2017), "Translating consumer's olive-oil quality-attribute requirements into optimal olive-growing practices: A quality function deployment (QFD) approach", British Food Journal, Vol. 119 No. 1, pp. 190-214.

Soon, J. M., Chandia, M. and Regenstein, J. M. (2017), "Halal integrity in the food supply chain", British Food Journal, Vol. 119, No. 1, pp. 39-51.

Stier, R. F. (2014). Food safety assurance systems: Documentation and record keeping. In, Y. Motarjemi (Ed.). Encyclopedia of Food Safety (Vol. 4). Academic Press, pp. 268-275.

Sweet, T., Balakrishnan, J., Robertson, B., Stolee, J. and Karim, S. (2010), "Applying quality function deployment in food safety management", British Food Journal, Vol. 112, No. 2, pp. 624-639.

Tambunan, T. (2009), "Export-oriented small and medium industry clusters in Indonesia", Journal of Enterprising Communities: People and Places in the Global Economy, Vol. 3 No. 1, pp. 25-58.

Tieman, M. and Ghazali, M. C. (2014), "Halal control activities and assurance activities in halal food logistics", Procedia-Social and Behavioral Sciences, Vol. 121, pp. 44-57. 
Van der Spiegel, M., van der Fels-Klerx, H. J., Sterrenburg, P., van Ruth, S. M., Scholtens-Toma, I. M. J. and Kok, E. J. (2012), "Halal assurance in food supply chains: Verification of halal certificates using audits and laboratory analysis", Trends in Food Science \& Technology, Vol. 27 No. 2, pp. 109-119.

Vatthanakul, S., Jangchud, A., Jangchud, K., Therdthai, N. and Wilkinson, B. (2010), "Gold kiwifruit leather product development using quality function deployment approach", Food Quality and Preference, Vol. 21, pp. 339-345.

Vlajic, J. V., Van der Vorst, J. G.; and Haijema, R. (2012), "A framework for designing robust food supply chains", International Journal of Production Economics, Vol. 137 No. 1, pp. 176-189.

Wilson, J. A. J. (2014), "The halal phenomenon: An extension or a new paradigm?" Social Business, Vol. 4 No. 3, pp. 255-271.

Wilson, J. A. J., and Liu, J. (2010), "Shaping the Halal into a brand?", Journal of Islamic Marketing, Vol. 1 No. 2, pp. 107-123.

Wilson, J. A. J., and Liu, J. (2011), "The challenged of Islamic branding: navigating emotions and halal", Journal of Islamic Marketing, Vol. 2 No. 1, pp. 28-42.

Zailani, S., Iranmanesh, M., Aziz, A. A. and Kanapathy, K. (2017), "Halal logistics opportunities and challenges", Journal of Islamic Marketing, Vol. 8 No. 1, pp. 127-139.

Zarei, M., Fakhrzad, M. B. and Paghaleh, M. J. (2011), "Food supply chain leanness using a developed QFD model", Journal of Food Engineering, Vol. 102 No. 1, pp. 25-33. 
Figure 1. Interrelated multi-phase QFD model for halal food control

Matrix 1: Halal assurance scheme (HAS) x Halal Food Processing

Matrix 2: Halal assurance scheme (HAS) x Halal Critical Factors

Matrix 3: Halal Critical Factors x Improvement programmes 
2

3

4

5

6

7

8

9

10

11

12

13

14

15

16

17

18

19

20

21

22

23

24

25

26

27

28

29

30

31

32

33

34

35

36

37

38

39

40

41

42

43

44

45

46

47

48

49

50

51

52

53

54

55

56

57

58

59

60

Table 1. Proposed first phase in matrix 1: The attributes of Halal Assurance System and Production Process Requirements

\begin{tabular}{|c|c|c|c|c|c|c|c|}
\hline \multirow{3}{*}{ The Attributes of Halal Assurance System } & \multirow{3}{*}{ 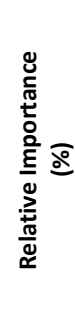 } & \multicolumn{6}{|c|}{ Process } \\
\hline & & \multicolumn{2}{|c|}{ 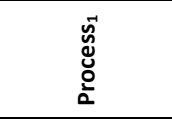 } & \multicolumn{2}{|c|}{$\vdots$} & \multicolumn{2}{|c|}{ 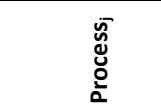 } \\
\hline & & $\begin{array}{l}\text { ¿̆ } \\
\text { un }\end{array}$ & 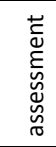 & 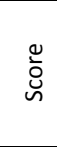 & 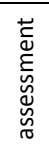 & 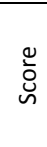 & 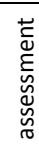 \\
\hline & $\mathrm{W}_{1}$ & $\mathrm{~S}_{11}$ & $\mathrm{H}_{11}$ & $\mathrm{~s}_{1 . . .}$ & $\mathrm{H}_{1 . . .}$ & $s_{1 j}$ & $\mathrm{H}_{1 j}$ \\
\hline $\mathrm{A}_{2}$ & $\mathrm{w}_{2}$ & $\mathrm{~S}_{21}$ & $\mathrm{H}_{21}$ & $s_{2 \ldots . .}$ & $\mathrm{H}_{2 \ldots}$ & $s_{2 j}$ & $\mathrm{H}_{2 \mathrm{j}}$ \\
\hline$A_{3}$ & $\mathrm{w}_{3}$ & $\mathrm{~S}_{31}$ & $\mathrm{H}_{31}$ & $\mathrm{~S}_{3 \ldots . .}$ & $\mathrm{H}_{3 . . .}$ & $\mathrm{S}_{3 \mathrm{j}}$ & $\mathrm{H}_{3 j}$ \\
\hline $\mathrm{A}_{4}$ & $w_{4}$ & $S_{41}$ & $\mathrm{H}_{41}$ & $\mathrm{~s}_{4 . \ldots}$ & $\mathrm{H}_{4 . \ldots}$ & $S_{4 j}$ & $\mathrm{H}_{4 j}$ \\
\hline 52 & $\ldots$ & $\ldots$ & $\ldots$ & $\ldots$ & $\ldots$ & $\ldots$ & $\ldots$ \\
\hline$A_{i}$ & $w_{i}$ & $s_{i 1}$ & $H_{i 1}$ & $s_{i}$ & $H_{i . . .}$ & $S_{i j}$ & $\mathrm{H}_{\mathrm{ij}}$ \\
\hline Absolute Importance & & & & & & & \\
\hline Percent Importance & & & & & & & \\
\hline Rank of priority & & & & & & & \\
\hline
\end{tabular}

Note: $H_{i j}=-, 0,1,3,9 \quad S_{i j}=W_{i} \times H_{i j}$ 
Table 2. Proposed second phase in matrix 2: The attributes of Halal Assurance System and Critical Halal Factors

\begin{tabular}{|c|c|c|c|c|c|c|c|c|}
\hline \multirow{3}{*}{$\begin{array}{l}\text { The Attributes of Halal Assurance } \\
\text { System }\end{array}$} & \multirow{3}{*}{ 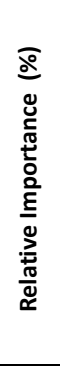 } & \multicolumn{6}{|c|}{ Critical halal factors } & \multirow{3}{*}{ 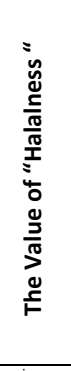 } \\
\hline & & \multicolumn{2}{|c|}{ 离 } & \multicolumn{2}{|c|}{$\vdots$} & \multicolumn{2}{|c|}{ 离 } & \\
\hline & & ڤँّ & 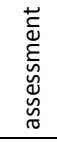 & ڤัٌ & 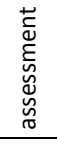 & ڤัँ & 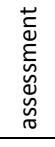 & \\
\hline & $\mathrm{W}_{1}$ & $\mathrm{~S}_{11}$ & $\mathrm{C}_{11}$ & $\mathrm{~S}_{1 \ldots}$ & $\mathrm{C}_{1 \ldots}$ & $S_{1 j}$ & $C_{1 j}$ & $\sum_{j=1}^{j} s 1 j$ \\
\hline$A_{2}$ & $W_{2}$ & $\mathrm{~S}_{21}$ & $\mathrm{C}_{21}$ & $\mathrm{~S}_{2 \ldots}$ & $\mathrm{C}_{2 \ldots}$ & $S_{2 j}$ & $C_{2 j}$ & $\sum_{j=1}^{j} s 2 j$ \\
\hline $\mathrm{A}_{3}$ & $W_{3}$ & $\mathrm{~S}_{31}$ & $\mathrm{C}_{31}$ & $\mathrm{~S}_{3 \ldots}$ & $C_{3 \ldots}$ & $S_{3 j}$ & $C_{3 j}$ & $\sum_{j=1}^{j} s 3 j$ \\
\hline $\mathrm{A}_{4}$ & $W_{4}$ & $\mathrm{~S}_{41}$ & $\mathrm{C}_{41}$ & $\mathrm{~S}_{4 . . .}$ & $\mathrm{C}_{4 . \ldots}$ & $S_{4 j}$ & $\mathrm{C}_{4 \mathrm{j}}$ & $\sum_{j=1}^{j} s 4 j$ \\
\hline$\cdots$ & $\ldots$ & $\cdots$ & $\cdots$ & & $\cdots$ & $\cdots$ & $\cdots$ & $\ldots$ \\
\hline$A_{i}$ & $w_{i}$ & $\mathrm{~S}_{\mathrm{i} 1}$ & $\mathrm{C}_{\mathrm{i} 1}$ & $\mathrm{~S}_{\mathrm{i} . . .}$ & $C_{i \ldots . .}$ & $\mathrm{S}_{\mathrm{ij}}$ & $C_{i j}$ & $\sum_{j=1} S i j$ \\
\hline Absolute Importance & & U) & & & & & & \\
\hline Percent Importance & & & & & & & & \\
\hline Rank of priority & & & & & & & & \\
\hline
\end{tabular}

Note: $C_{i j}=-, 1,3,9 \quad S_{i j}=W_{i} \times C_{i j}$ 
Table 3. Proposed third phase in matrix 3: Critical halal factors and improvement programmes

\begin{tabular}{|c|c|c|c|c|c|c|c|c|c|c|c|c|c|c|c|c|}
\hline \multirow{4}{*}{ 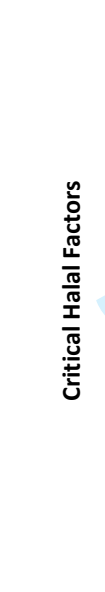 } & \multirow{4}{*}{$\begin{array}{l}\text { Problems in } \\
\text { Critical Halal } \\
\text { Factors }\end{array}$} & \multirow{4}{*}{\multicolumn{2}{|c|}{ 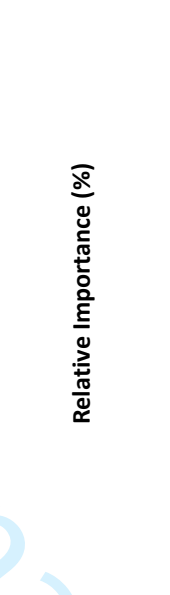 }} & \multicolumn{12}{|c|}{ Improvement Programmes } & \multirow{4}{*}{ Criticality } \\
\hline & & & & \multicolumn{4}{|c|}{ 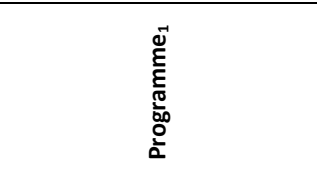 } & \multicolumn{4}{|c|}{ 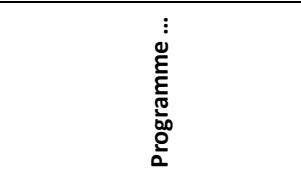 } & \multicolumn{4}{|c|}{ 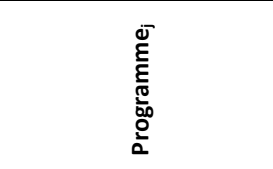 } & \\
\hline & & & & \multicolumn{2}{|c|}{ 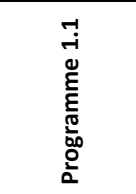 } & \multicolumn{2}{|c|}{ 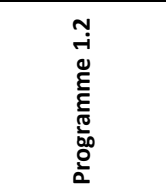 } & \multicolumn{2}{|c|}{ 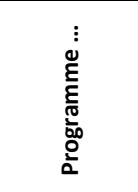 } & \multicolumn{2}{|c|}{ 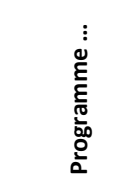 } & \multicolumn{2}{|c|}{ 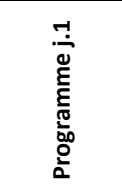 } & \multicolumn{2}{|c|}{ 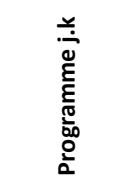 } & \\
\hline & & & & ڤัँ & 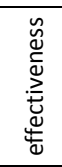 & 产 & 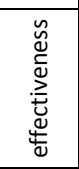 & 㐫 & 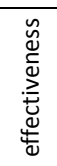 & ڤัँ & 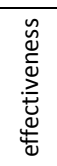 & ڤัँ & 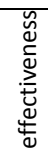 & ڤัँ & 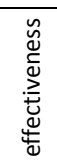 & \\
\hline \multirow{3}{*}{ Factor 1} & $\mathrm{~F}_{11}$ & \multirow{3}{*}{$\mathrm{W}_{1}$} & $\mathrm{~W}_{11}$ & $\mathrm{~S}_{111}$ & $\mathrm{E}_{111}$ & $\mathrm{~S}_{121}$ & $E_{121}$ & $\mathrm{~S}_{1 \ldots .}$ & $\mathrm{E}_{1 \ldots}$ & $\mathrm{S}_{1 \ldots}$ & $\mathrm{E}_{1 \ldots}$ & $\mathrm{S}_{1 \mathrm{j}, 1}$ & $E_{1 j 1}$ & $\mathrm{~S}_{1 \mathrm{jk}}$ & $E_{1 j k}$ & $\sum_{j=1}^{j} s 1 j k$ \\
\hline & $\mathrm{F}_{1 \ldots}$ & & $W_{1 . .}$ & $\mathrm{S}_{11 . .}$ & $\mathrm{E}_{11 . .}$ & $\mathrm{S}_{12 . .}$ & $E_{12 . .}$ & $\ldots$ & $\ldots$ & $\ldots$ & $\ldots$ & $\ldots$ & $\ldots$ & $\ldots$ & $\ldots$ & $\ldots$ \\
\hline & $F_{1 n}$ & & $W_{1 \mathrm{n}}$ & $\mathrm{S}_{1 \mathrm{n}}$ & $E_{1 n}$ & $S_{12 n}$ & $E_{12 n}$ & $\ldots$ & $\cdots$ & $\ldots$ & $\ldots$ & $\ldots$ & $\ldots$ & $\ldots$ & $\ldots$ & $\cdots$ \\
\hline \multirow{3}{*}{ Factor 2} & $\mathrm{~F}_{21}$ & \multirow{3}{*}{$W_{2}$} & $W_{21}$ & $\mathrm{~S}_{21 \mathrm{i}}$ & $E_{211}$ & $S_{221}$ & $\mathrm{E}_{221}$ & $\cdots$ & $\cdots$ & $\cdots$ & $\cdots$ & $\cdots$ & $\cdots$ & $\cdots$ & $\cdots$ & $\cdots$ \\
\hline & $F_{2 \ldots}$ & & $W_{2}$ & $\mathrm{~S}_{2 \ldots \ldots}$ & $E_{2, \ldots}$ & $S_{22 . .}$ & $\mathrm{E}_{22 . .}$ & $\cdots$ & $\cdots$ & $\cdots$ & $\ldots$ & $\ldots$ & $\ldots$ & $\ldots$ & $\ldots$ & $\cdots$ \\
\hline & $F_{2 n}$ & & $W_{2 n}$ & $S_{21 n}$ & $E_{21 n}$ & $S_{22 n}$ & $E_{22 n}$ & $\cdots$ & $\cdots$ & $\cdots$ & $\ldots$ & $\ldots$ & $\cdots$ & $\cdots$ & $\cdots$ & $\cdots$ \\
\hline \multirow{3}{*}{ Factor .. } & $F_{\ldots 1}$ & \multirow{3}{*}{$W_{\ldots}$} & $W_{\ldots 1}$ & S...11 & E..11 & S..21 & E...21 & $\cdots$ & $\cdots$ & $\ldots$ & $\ldots$ & $\ldots$ & $\ldots$ & $\ldots$ & $\ldots$ & $\ldots$ \\
\hline & $F_{\ldots, \ldots, \ldots}$ & & $W_{\ldots, \ldots}$ & $\mathrm{S}_{. .11}$ & $\mathrm{E}_{\ldots 1 .}$ & $S_{\ldots ., 2 . .}$ & $E_{\ldots ., \ldots}$ & $\cdots$ & $\cdots$ & $\cdots$ & $\ldots$ & $\ldots$ & $\cdots$ & $\cdots$ & $\ldots$ & $\cdots$ \\
\hline & $\mathrm{F}_{\ldots \mathrm{n}}$ & & $\mathrm{W}_{\ldots, \mathrm{n}}$ & S...1n & $\mathrm{E}_{.1 \mathrm{n}}$ & $\mathrm{S}_{\mathrm{S} \ldots . \mathrm{n}}$ & $E_{\ldots, \ldots n}$ & $\ldots$ & $\ldots$ & $\ldots$ & $\ldots$ & $\ldots$ & $\ldots$ & $\ldots$ & 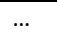 & $\cdots$ \\
\hline \multirow{3}{*}{ Factor $\mathrm{i}$} & $\mathrm{F}_{\mathrm{i} 1}$ & \multirow{3}{*}{$W_{i}$} & $\mathrm{~W}_{\mathrm{i} 1}$ & $\mathrm{~S}_{\mathrm{i} 1 \mathrm{i}}$ & $E_{i 1 i}$ & $\mathrm{~S}_{\mathrm{i} 2 \mathrm{i}}$ & $\mathrm{E}_{\mathrm{i} 2 \mathrm{i}}$ & $\cdots$ & $\cdots$ & $\cdots$ & $\cdots$ & $\cdots$ & $\cdots$ & $\cdots$ & $\cdots$ & $\cdots$ \\
\hline & $\mathrm{F}_{\mathrm{i} . . .}$ & & $\mathrm{W}_{\mathrm{i} . . .}$ & $S_{i \ldots, . .}$ & $\mathrm{E}_{\mathrm{i}, \ldots . .}$ & $\mathrm{S}_{\mathrm{i} 2 . .}$ & $E_{i 2 . .}$ & $\cdots$ & $\cdots$ & $\cdots$ & $\cdots$ & $\cdots$ & $\ldots$ & $\cdots$ & $\cdots$ & $\cdots$ \\
\hline & $F_{\text {in }}$ & & $W_{\text {in }}$ & $\mathrm{S}_{\mathrm{i} 1 \mathrm{n}}$ & $E_{i 1 n}$ & $\mathrm{~S}_{\mathrm{i} n}$ & $E_{i 2 n}$ & $S_{\text {in.. }}$ & Ein... & $S_{\text {in... }}$ & $E_{\text {in... }}$ & $S_{\text {in }}$ & $E_{1 j 1}$ & $S_{\text {in }}$ & $E_{i j k}$ & $\sum_{j=1}^{j} s i j k$ \\
\hline \multicolumn{4}{|c|}{ Absolute effectiveness } & \multicolumn{2}{|c|}{$\sum_{j=1}^{j} s 1 j$} & \multicolumn{2}{|c|}{$\sum_{j=1}^{j} S 12 n$} & \multicolumn{2}{|c|}{$\sum_{j=1}^{j} S i j \ldots$} & \multicolumn{2}{|c|}{$\sum_{j=1}^{j} S i j}$. & \multicolumn{2}{|c|}{$\sum_{j=1}^{j} S i j$} & \multicolumn{2}{|c|}{$\sum_{j=1}^{j} S i j$} & \\
\hline \multicolumn{4}{|c|}{ Percent effectiveness } & \multicolumn{2}{|c|}{$\mathrm{P}_{11}$} & & & & & & & & & & & \\
\hline & Rank of priori & & & & & & & & & & & & & & & \\
\hline
\end{tabular}


Table 4 Application of first phase of QFD model in chicken processing plant

\begin{tabular}{|c|c|c|c|c|c|c|c|c|c|c|c|c|c|c|c|c|c|c|}
\hline \multirow{3}{*}{ The attributes of Halal Assurance System } & \multirow{3}{*}{ 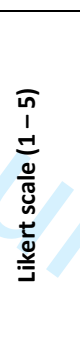 } & \multirow{3}{*}{ 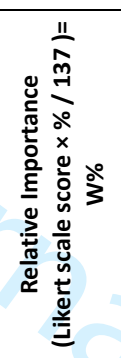 } & \multicolumn{16}{|c|}{ Process } \\
\hline & & & \multicolumn{2}{|c|}{ 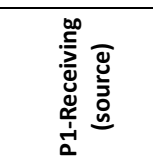 } & \multicolumn{2}{|c|}{ 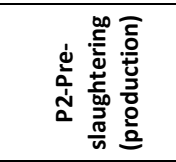 } & \multicolumn{2}{|c|}{ 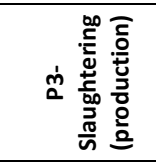 } & \multicolumn{2}{|c|}{ 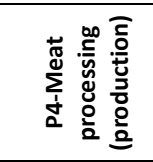 } & \multicolumn{2}{|c|}{ 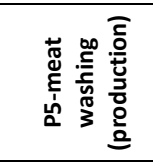 } & \multicolumn{2}{|c|}{ 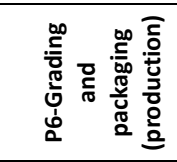 } & \multicolumn{2}{|c|}{ 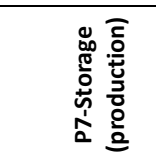 } & \multicolumn{2}{|c|}{ 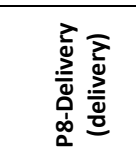 } \\
\hline & & & $\stackrel{0}{\grave{\nu}}$ & 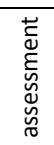 & 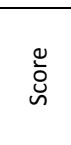 & 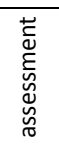 & 范 & 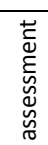 & 苛 & 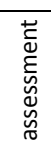 & 莒 & 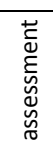 & $\stackrel{0}{\stackrel{0}{\circ}}$ & 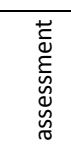 & 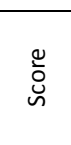 & 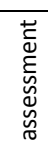 & 范 & 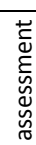 \\
\hline A1 Stress-free living chicken & 5 & $3.65 \%$ & 0.33 & 9 & 0.22 & 6 & 0.22 & 6 & 0.04 & 1 & & & & & & & & \\
\hline A2 Ante mortem check result & 3 & $2.19 \%$ & 0.07 & 3 & 0.07 & 3 & 0.07 & 3 & & & & & & & & & 0.02 & 1 \\
\hline A3 Devout Muslim & 5 & $3.65 \%$ & & & 0.33 & 9 & 0.11 & 3 & 0.11 & 3 & & & & & & & 0.04 & 1 \\
\hline A4 Understand Islamic slaughtering rules & 5 & $3.65 \%$ & & & 0.33 & 9 & 0.11 & 3 & 0.11 & 3 & & & & & & & 0.04 & 1 \\
\hline A5 Healthy body and soul & 5 & $3.65 \%$ & & & & & 0.22 & 6 & 0.11 & 3 & 0.11 & 3 & & & & & 0.04 & 1 \\
\hline $\begin{array}{l}\text { A6 Good ratio between number of } \\
\text { slaughterer and chicken }\end{array}$ & 4 & $2.92 \%$ & & & & & 0.26 & 9 & & & & & & & & & & \\
\hline A7 Sharp slaughtering tools & 5 & $3.65 \%$ & & & & & 0.33 & 9 & & & & & & & & & & \\
\hline $\begin{array}{l}\text { A8 Fulfils criteria from LPPOM MUI and } \\
\text { veterinary department }\end{array}$ & 5 & $3.65 \%$ & 0.04 & 1 & 0.22 & 6 & 0.33 & 9 & 0.33 & 9 & 0.22 & 6 & 0.11 & 3 & 0.11 & 3 & 0.11 & 3 \\
\hline A9 Evidence of halal certification & 5 & $3.65 \%$ & 0.04 & 1 & & & & & 0.33 & 9 & & & 0.11 & 3 & 0.11 & 3 & 0.11 & 3 \\
\hline $\begin{array}{l}\text { A10 Free from najs (unclean items) and } \\
\text { haram (non-permissible) contamination }\end{array}$ & 5 & $3.65 \%$ & 0.11 & 3 & 0.11 & 3 & & & 0.33 & 9 & 0.11 & 3 & 0.11 & 3 & 0.33 & 9 & 0.33 & 9 \\
\hline $\begin{array}{l}\text { A11 } \\
\text { Segregated slaughterhouse for halal } \\
\text { chicken meat }\end{array}$ & 5 & $3.65 \%$ & 0.33 & 9 & & & 0.33 & 9 & 0.33 & 9 & & & 0.33 & 9 & 0.33 & 9 & 0.33 & 9 \\
\hline $\begin{array}{l}\text { A12 Clearly separated from other pig } \\
\text { slaughterhouse and contamination sources }\end{array}$ & 5 & $3.65 \%$ & 0.33 & 9 & & & 0.33 & 9 & 0.33 & 9 & & & 0.33 & 9 & 0.33 & 9 & 0.33 & 9 \\
\hline A13 Avoid non-halal residual waste & 5 & $3.65 \%$ & 0.33 & 9 & & & 0.33 & 9 & 0.33 & 9 & & & 0.33 & 9 & & & 0.33 & 9 \\
\hline $\begin{array}{l}\text { A14 Short unconscious period with } \\
\text { minimal pain and distress }\end{array}$ & 5 & $3.65 \%$ & & & & & 0.33 & 9 & 0.04 & 1 & 0.04 & 1 & & & & & & \\
\hline A15 Appropriate tools to stun the animal & 5 & $3.65 \%$ & & & & & 0.11 & 3 & 0.04 & 1 & & & & & & & & \\
\hline $\begin{array}{l}\text { A16 Stunning method must be validated to } \\
\text { meet the requirements }\end{array}$ & 4 & $2.92 \%$ & & & 0.26 & 9 & 0.26 & 9 & & & & & & & & & & \\
\hline A17 Stunning tool maintenance plan & 4 & $2.92 \%$ & & & 0.18 & 6 & 0.26 & 9 & 0.26 & 9 & 0.18 & 6 & 0.03 & 1 & 0.18 & 6 & 0.09 & 3 \\
\hline $\begin{array}{l}\text { A18 Procedure for stunning \& slaughtering } \\
\text { and effectiveness of tools are validated } \\
\text { and verified }\end{array}$ & 4 & $2.92 \%$ & & & & & 0.26 & 9 & 0.03 & 1 & 0.09 & 3 & & & & & & \\
\hline $\begin{array}{l}\text { A19 Pronounce 'tasmiyah' (blessing) upon } \\
\text { each animal immediately before } \\
\text { slaughtering }\end{array}$ & 5 & $3.65 \%$ & & & & & 0.33 & 9 & & & & & & & & & & \\
\hline
\end{tabular}




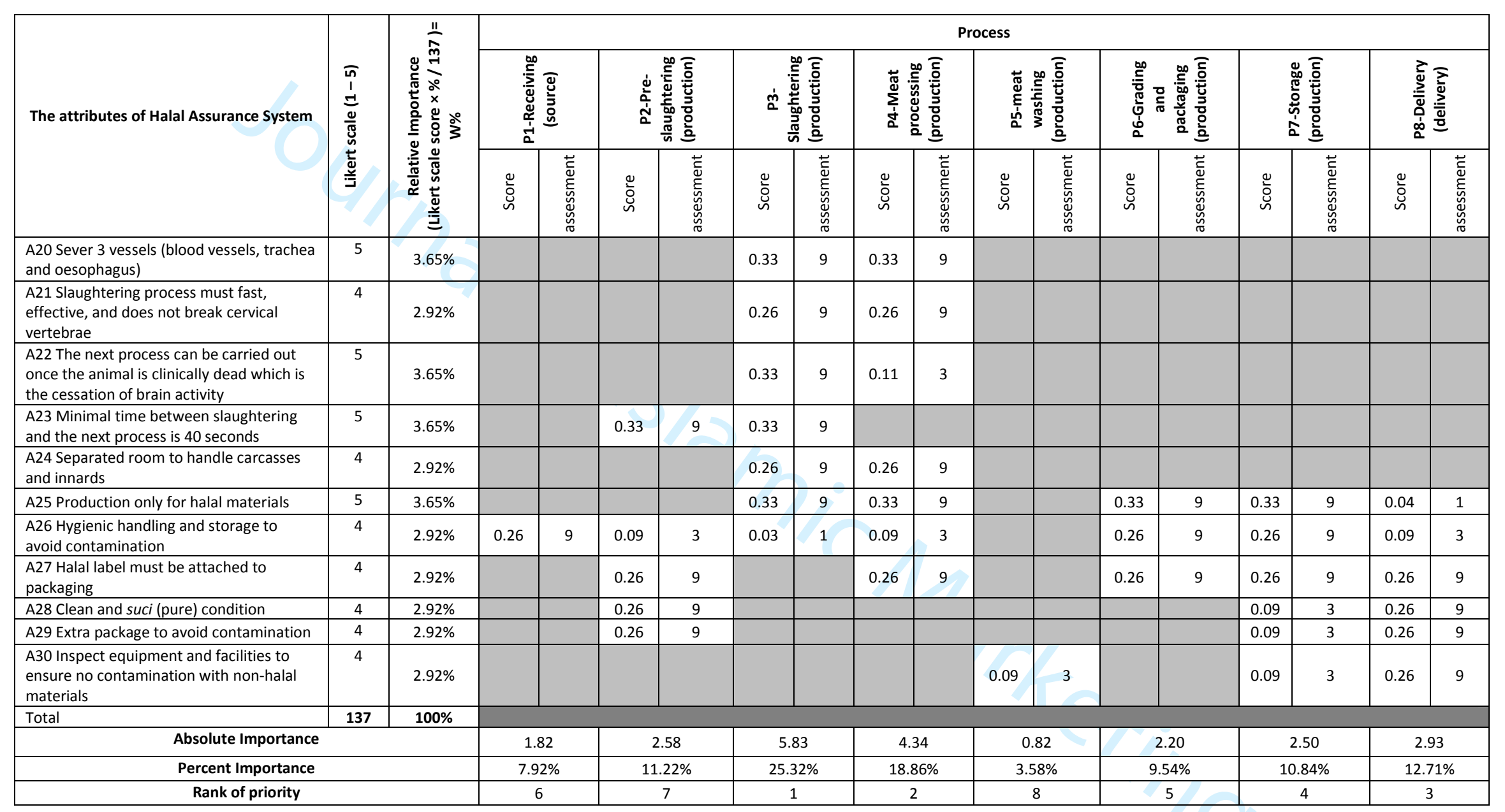


Table 5 Application of second phase of QFD model in chicken processing plant

\begin{tabular}{|c|c|c|c|c|c|c|c|c|c|c|c|c|c|}
\hline \multirow{3}{*}{ The attributes of Halal Assurance System } & \multirow{3}{*}{ 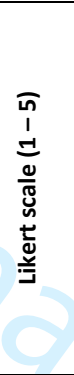 } & \multirow{3}{*}{ 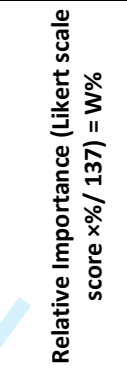 } & \multicolumn{10}{|c|}{ Critical Halal Factors } & \multirow{3}{*}{ 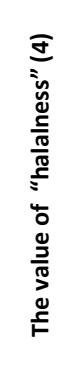 } \\
\hline & & & \multicolumn{2}{|c|}{ 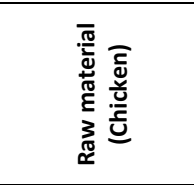 } & \multicolumn{2}{|c|}{ 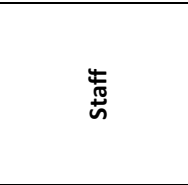 } & \multicolumn{2}{|c|}{ 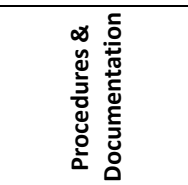 } & \multicolumn{2}{|c|}{ 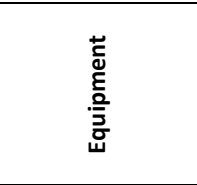 } & \multicolumn{2}{|c|}{ 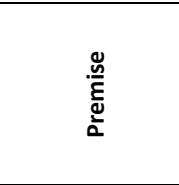 } & \\
\hline & & & $\stackrel{0}{\stackrel{0}{u}}$ & 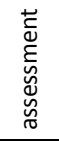 & 䒕 & 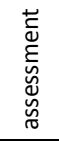 & $\stackrel{0}{\check{L}}$ & 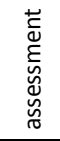 & $\stackrel{0}{\grave{L}}$ & 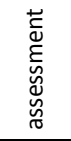 & $\stackrel{0}{\breve{\Xi}}$ & 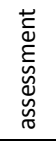 & \\
\hline A1 Stress-free living chicken & 5 & $3.65 \%$ & 0.33 & 9 & & & 0.04 & 1 & & & & & 0.37 \\
\hline A2 Ante mortem check result & 3 & $2.19 \%$ & 0.07 & 3 & & & 0.07 & 3 & & & & & 0.14 \\
\hline A3 Devout Muslim & 5 & $3.65 \%$ & & & 0.04 & 1 & & & & & & & 0.04 \\
\hline A4 Understand Islamic slaughtering rules & 5 & $3.65 \%$ & & & 0.04 & 1 & & & & & & & 0.04 \\
\hline A5 Healthy body and soul & 5 & $3.65 \%$ & & & 0.11 & 3 & & & & & & & 0.11 \\
\hline $\begin{array}{l}\text { A6 } \\
\text { Good ratio between number of slaughterer and chicken }\end{array}$ & 4 & $2.92 \%$ & & & 0.26 & 9 & & & & & & & 0.26 \\
\hline A7 Sharp slaughtering tools & 5 & $3.65 \%$ & & & & & & & 0.04 & 1 & & & 0.04 \\
\hline $\begin{array}{l}\text { A8 Fulfils criteria from AIFDC-ICU and veterinary } \\
\text { department }\end{array}$ & 5 & $3.65 \%$ & & & & & 0.11 & 3 & & & & & 0.11 \\
\hline A9 Evidence of halal certification & 5 & $3.65 \%$ & & & & & 0.33 & 9 & & & & & 0.33 \\
\hline $\begin{array}{l}\text { A10 Free from najs (unclean items) and haram (non- } \\
\text { permissible) contamination }\end{array}$ & 5 & $3.65 \%$ & & & & & & & & & 0.04 & 1 & 0.04 \\
\hline $\begin{array}{l}\text { A11 } \\
\text { Segregated slaughterhouse for halal chicken meat }\end{array}$ & 5 & $3.65 \%$ & & & 0.33 & 9 & 0.11 & 3 & & & & & 0.44 \\
\hline $\begin{array}{l}\text { A12 Clearly separated from other pig slaughterhouse and } \\
\text { contamination sources }\end{array}$ & 5 & $3.65 \%$ & & & & & & & 0.04 & 1 & 0.04 & 1 & 0.08 \\
\hline A13 Avoid non-halal residual waste & 5 & $3.65 \%$ & & & & & & & 0.04 & 1 & 0.11 & 3 & 0.15 \\
\hline $\begin{array}{l}\text { A14 Short unconscious period with minimal pain and } \\
\text { distress }\end{array}$ & 5 & $3.65 \%$ & 0.11 & 3 & & & & & 0.04 & 1 & & & 0.15 \\
\hline A15 Appropriate tools to stun the animal & 5 & $3.65 \%$ & & & & & & & 0.11 & 3 & & & 0.11 \\
\hline $\begin{array}{l}\text { A16 Stunning method must be validated to meet the } \\
\text { requirements }\end{array}$ & 4 & $2.92 \%$ & & & & & & & 0.09 & 3 & & & 0.09 \\
\hline A17 Stunning tool maintenance plan & 4 & $2.92 \%$ & & & & & 0.09 & 3 & 0.09 & 3 & & & 0.18 \\
\hline $\begin{array}{l}\text { A18 Procedure for stunning \& slaughtering and } \\
\text { effectiveness of tools are validated and verified }\end{array}$ & 4 & $2.92 \%$ & & & & & 0.09 & 3 & 0.26 & 9 & & & 0.35 \\
\hline $\begin{array}{l}\text { A19 Pronounce 'tasmiyah' (blessing) upon each animal } \\
\text { immediately before slaughtering }\end{array}$ & 5 & $3.65 \%$ & & & 0.04 & 1 & & & & & & & 0.04 \\
\hline $\begin{array}{l}\text { A20 Sever } 3 \text { vessels (blood vessels, trachea and } \\
\text { oesophagus) }\end{array}$ & 5 & $3.65 \%$ & & & & & & & 0.11 & 3 & & & 0.11 \\
\hline
\end{tabular}




\begin{tabular}{|c|c|c|c|c|c|c|c|c|c|c|c|c|c|}
\hline \multirow{3}{*}{ The attributes of Halal Assurance System } & \multirow{3}{*}{ 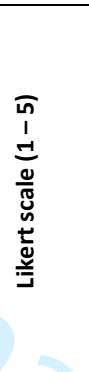 } & \multirow{3}{*}{ 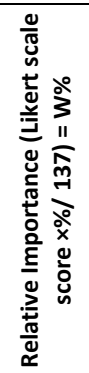 } & \multicolumn{10}{|c|}{ Critical Halal Factors } & \multirow{3}{*}{ 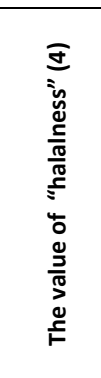 } \\
\hline & & & \multicolumn{2}{|c|}{ 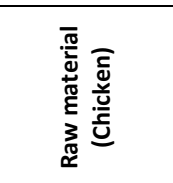 } & \multicolumn{2}{|c|}{ 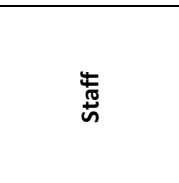 } & \multicolumn{2}{|c|}{ 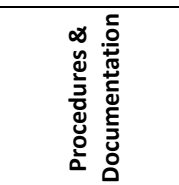 } & \multicolumn{2}{|c|}{ 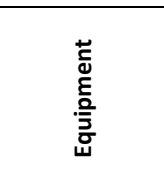 } & \multicolumn{2}{|c|}{ 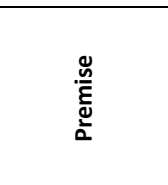 } & \\
\hline & & & 气ัّ & 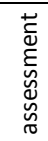 & 范 & 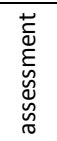 & $\stackrel{0}{\check{\Xi}}$ & 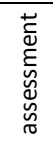 & $\stackrel{0}{\breve{0}}$ & 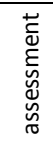 & $\stackrel{0}{\breve{u}}$ & 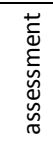 & \\
\hline $\begin{array}{l}\text { A21 Slaughtering process must fast, effective, and does } \\
\text { not break cervical vertebrae }\end{array}$ & 4 & $2.92 \%$ & 0.03 & 1 & 0.09 & 3 & & & & & & & 0.12 \\
\hline $\begin{array}{l}\text { A22 The next process can be carried out once the animal is } \\
\text { clinically dead which is the cessation of brain activity }\end{array}$ & 5 & $3.65 \%$ & & & 0.11 & 3 & & & & & 0.04 & 1 & 0.15 \\
\hline $\begin{array}{l}\text { A23 Minimal time between slaughtering and the next } \\
\text { process is } 40 \text { seconds }\end{array}$ & 5 & $3.65 \%$ & & & 0.11 & 3 & & & 0.33 & 9 & & & 0.44 \\
\hline A24 Separated room to handle carcasses and innards & 4 & $2.92 \%$ & & & & & & & & & 0.09 & 3 & 0.09 \\
\hline A25 Production only for halal materials & 5 & $3.65 \%$ & & & & & & & 0.04 & 1 & 0.04 & 1 & 0.08 \\
\hline A26 Hygienic handling and storage to avoid contamination & 4 & $2.92 \%$ & & & & & & & 0.03 & 1 & 0.09 & 3 & 0.12 \\
\hline A27 Halal label must be attached to packaging & 4 & $2.92 \%$ & & & & & 0.03 & 1 & - & - & 0.03 & 1 & 0.06 \\
\hline A28 Clean and suci (pure) condition & 4 & $2.92 \%$ & 0.03 & 1 & & & & & 0.26 & 9 & 0.09 & 3 & 0.38 \\
\hline A29 Extra package to avoid contamination & 4 & $2.92 \%$ & & & & & & & 0.09 & 3 & 0.03 & 1 & 0.12 \\
\hline \multirow[t]{2}{*}{$\begin{array}{l}\text { A30 Inspect equipment and facilities to ensure no } \\
\text { contamination with non-halal material }\end{array}$} & 4 & $2.92 \%$ & & & & & 0.26 & 9 & 0.03 & 1 & 0.03 & 1 & 0.32 \\
\hline & 137 & $100 \%$ & \multirow{2}{*}{\multicolumn{2}{|c|}{0.56}} & & & & & & & & & \\
\hline \multicolumn{3}{|l|}{ Absolute importance } & & & \multicolumn{2}{|c|}{1.12} & 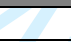 & & \multicolumn{2}{|c|}{1.58} & \multicolumn{2}{|c|}{0.61} & 4.98 \\
\hline \multicolumn{3}{|l|}{ Percent importance } & \multicolumn{2}{|c|}{$11.29 \%$} & \multicolumn{2}{|c|}{$22.43 \%$} & & & \multicolumn{2}{|c|}{$31.67 \%$} & \multicolumn{2}{|c|}{$12.17 \%$} & $100.00 \%$ \\
\hline \multicolumn{3}{|l|}{ Rank of priority } & \multicolumn{2}{|c|}{4} & \multicolumn{2}{|c|}{2} & & & \multicolumn{2}{|c|}{1} & \multicolumn{2}{|c|}{3} & \\
\hline
\end{tabular}


Table 6 Application of third phase of QFD model in chicken processing plant

\begin{tabular}{|c|c|c|c|c|c|c|c|c|c|c|c|c|c|c|c|c|c|c|}
\hline \multirow{4}{*}{ 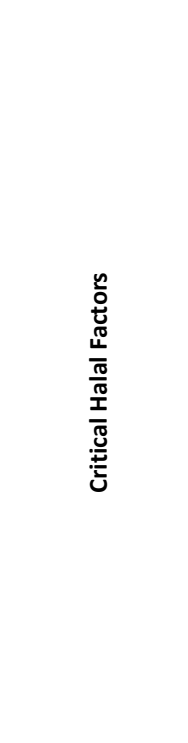 } & \multirow{4}{*}{ Problems in Critical Halal Factors } & \multirow{4}{*}{ 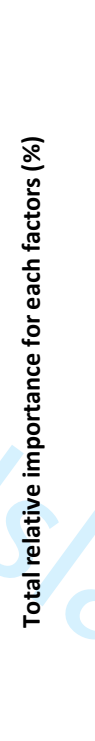 } & \multirow{4}{*}{\multicolumn{2}{|c|}{ 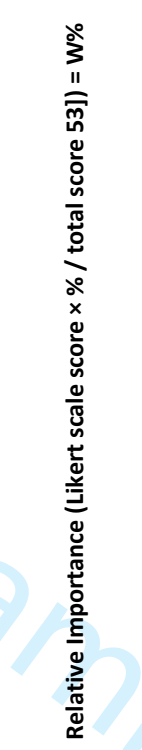 }} & \multicolumn{12}{|c|}{ Improvement Programmes } & & \\
\hline & & & & & \multicolumn{4}{|c|}{ 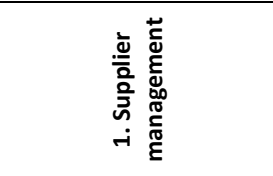 } & \multicolumn{4}{|c|}{ 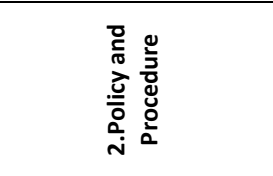 } & \multicolumn{4}{|c|}{ 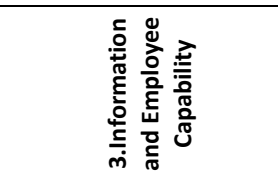 } & & \\
\hline & & & & & \multicolumn{2}{|c|}{ 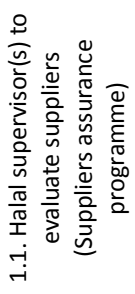 } & \multicolumn{2}{|c|}{ 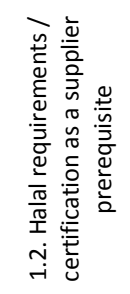 } & \multicolumn{2}{|c|}{ 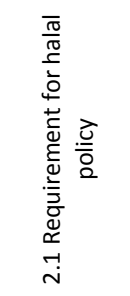 } & \multicolumn{2}{|c|}{ 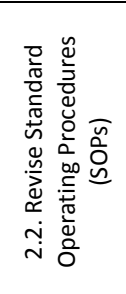 } & \multicolumn{2}{|c|}{ 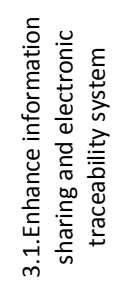 } & \multicolumn{2}{|c|}{ 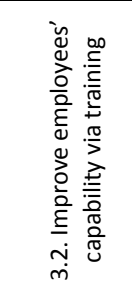 } & \multicolumn{2}{|c|}{ Criticalit } \\
\hline & & & & & 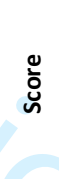 & 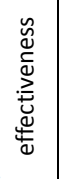 & $\stackrel{0}{\grave{L}}$ & 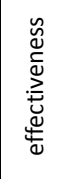 & 总 & 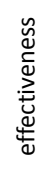 & 㐫 & 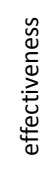 & $\stackrel{0}{\grave{L}}$ & 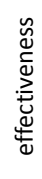 & $\stackrel{0}{\grave{L}}$ & 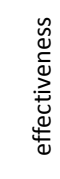 & & \\
\hline \multirow{2}{*}{ Chicken } & C01 Animal welfare is still lacking & \multirow{2}{*}{$\begin{array}{c}18.87 \\
\%\end{array}$} & 5 & $\begin{array}{c}9.43 \\
\%\end{array}$ & $\begin{array}{c}0.2 \\
8\end{array}$ & 3 & $\begin{array}{c}0.2 \\
8\end{array}$ & 3 & $\begin{array}{c}0.0 \\
9\end{array}$ & 1 & - & - & $\begin{array}{c}0.0 \\
9\end{array}$ & 1 & $\begin{array}{c}0.8 \\
5\end{array}$ & 9 & 1.60 & 3 \\
\hline & $\begin{array}{l}\text { C02 Lack of awareness among chicken suppliers regarding } \\
\text { importance of halal and halal certification }\end{array}$ & & 5 & $\begin{array}{c}9.43 \\
\%\end{array}$ & $\begin{array}{c}0.8 \\
5\end{array}$ & 9 & $\begin{array}{c}0.8 \\
5\end{array}$ & 9 & $\begin{array}{c}0.2 \\
8\end{array}$ & 3 & $\begin{array}{c}0.2 \\
8\end{array}$ & 3 & $\begin{array}{c}0.2 \\
8\end{array}$ & 3 & - & - & $\begin{array}{c}2.55 \\
*\end{array}$ & 1 \\
\hline \multirow{2}{*}{ Human } & H01 Lack of competency in halal slaughtering & \multirow{2}{*}{$\begin{array}{c}16.98 \\
\%\end{array}$} & 5 & $\begin{array}{c}9.43 \\
\%\end{array}$ & - & - & - & - & $\begin{array}{c}0.2 \\
8\end{array}$ & 3 & - & - & - & - & $\begin{array}{c}0.8 \\
5\end{array}$ & 9 & 1.13 & 5 \\
\hline & $\begin{array}{l}\text { H02 Number of slaughterers are not proportional to the number of } \\
\text { chickens }\end{array}$ & & 4 & $\begin{array}{c}7.55 \\
\%\end{array}$ & - & - & - & - & - & - & - & - & - & - & $\begin{array}{c}0.6 \\
8\end{array}$ & 9 & 0.68 & 6 \\
\hline \multirow{4}{*}{ Documentation } & D01 Incomplete halal procedure & \multirow{4}{*}{$\begin{array}{c}32.08 \\
\%\end{array}$} & 4 & $\begin{array}{c}7.55 \\
\%\end{array}$ & - & - & - & - & $\begin{array}{c}0.2 \\
3\end{array}$ & 3 & $\begin{array}{c}0.6 \\
8\end{array}$ & 9 & - & - & - & - & 0.91 & \\
\hline & $\begin{array}{l}\text { D02 Lack of evidence or supporting materials about halal procedure } \\
\text { and certification }\end{array}$ & & 5 & $\begin{array}{c}9.43 \\
\%\end{array}$ & $\begin{array}{c}0.2 \\
8\end{array}$ & 3 & $\begin{array}{c}0.8 \\
5\end{array}$ & 9 & $\begin{array}{c}0.0 \\
9\end{array}$ & 1 & - & - & - & - & - & - & 1.23 & 4 \\
\hline & D03 Suppliers without halal certification & & 4 & $\begin{array}{c}7.55 \\
\%\end{array}$ & $\begin{array}{c}0.2 \\
3\end{array}$ & 3 & $\begin{array}{c}0.2 \\
3\end{array}$ & 3 & $\begin{array}{c}0.0 \\
8\end{array}$ & 1 & - & - & - & - & - & - & 0.53 & 7 \\
\hline & D04 Lack of documentation and records for maintenance tools & & 4 & $\begin{array}{c}7.55 \\
\%\end{array}$ & $\begin{array}{c}0.2 \\
3\end{array}$ & 3 & $\begin{array}{c}0.2 \\
3\end{array}$ & 3 & $\begin{array}{c}0.0 \\
8\end{array}$ & 1 & - & - & - & - & - & - & 0.53 & 7 \\
\hline Tools & $\begin{array}{l}\text { T01 Absence of timer to ensure minimal time ( } 40 \text { secs) between } \\
\text { slaughtering to next process is observed }\end{array}$ & $\begin{array}{c}24.53 \\
\%\end{array}$ & 5 & $\begin{array}{c}9.43 \\
\%\end{array}$ & ـ & - & - & - & $\begin{array}{c}0.8 \\
5\end{array}$ & 9 & $\begin{array}{c}0.8 \\
5\end{array}$ & 9 & - & - & $\begin{array}{c}0.2 \\
8\end{array}$ & 3 & $\begin{array}{c}1.98 \\
* *\end{array}$ & 2 \\
\hline
\end{tabular}




\begin{tabular}{|c|c|c|c|c|c|c|c|c|c|c|c|c|c|c|c|c|c|c|}
\hline \multirow{6}{*}{ 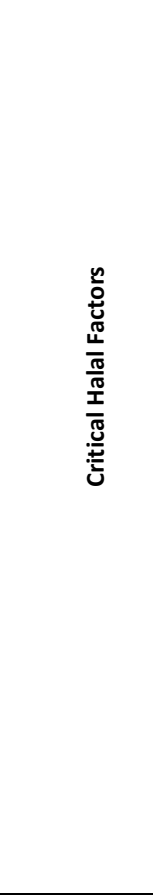 } & \multirow{4}{*}{ Problems in Critical Halal Factors } & \multirow{6}{*}{ 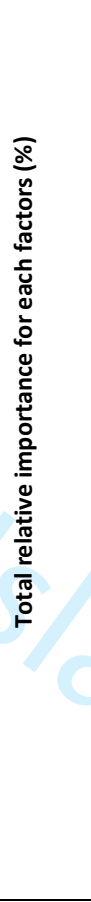 } & \multirow{4}{*}{\multicolumn{2}{|c|}{ 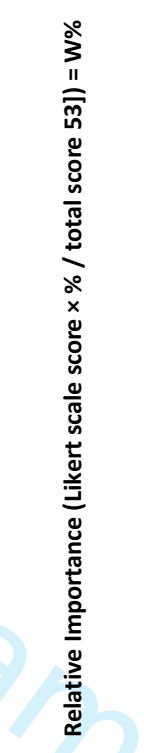 }} & \multicolumn{12}{|c|}{ Improvement Programmes } & & \\
\hline & & & & & \multicolumn{4}{|c|}{ 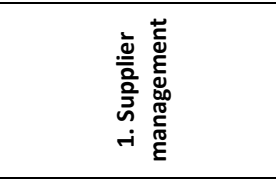 } & \multicolumn{4}{|c|}{ 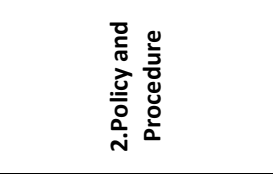 } & \multicolumn{4}{|c|}{ 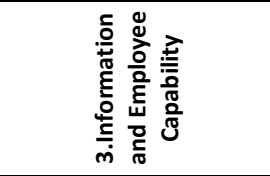 } & & \\
\hline & & & & & \multicolumn{2}{|c|}{ 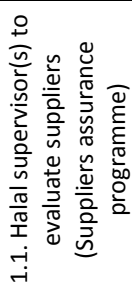 } & \multicolumn{2}{|c|}{ 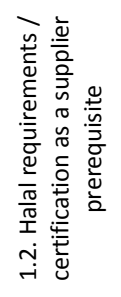 } & \multicolumn{2}{|c|}{ 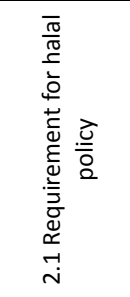 } & \multicolumn{2}{|c|}{ 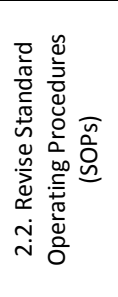 } & \multicolumn{2}{|c|}{ 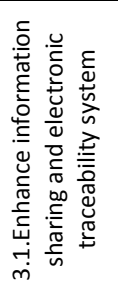 } & \multicolumn{2}{|c|}{ 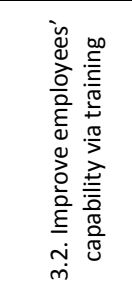 } & \multicolumn{2}{|c|}{ Criticality } \\
\hline & & & & & ڤั้ & 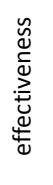 & 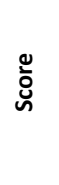 & 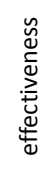 & ڤัँ & 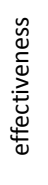 & ڤัँ & 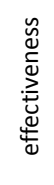 & ڤัँ & 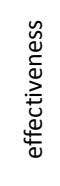 & $\stackrel{0}{\breve{u ̈}}$ & 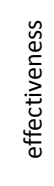 & & \\
\hline & T02 Cleaning tools inappropriate and may cause cross contamination & & 4 & $\begin{array}{c}7.55 \\
\%\end{array}$ & - & - & - & - & $\begin{array}{c}0.2 \\
3\end{array}$ & 3 & $\begin{array}{c}0.2 \\
3\end{array}$ & 3 & - & - & $\begin{array}{c}0.6 \\
8\end{array}$ & 9 & 1.13 & 5 \\
\hline & $\begin{array}{l}\text { T03 Periodic verification and validation procedures carried out for all } \\
\text { tools }\end{array}$ & & 4 & $\begin{array}{c}7.55 \\
\%\end{array}$ & - & & & - & $\begin{array}{c}0.2 \\
3\end{array}$ & 3 & $\begin{array}{c}0.6 \\
8\end{array}$ & 9 & - & - & $\begin{array}{c}0.2 \\
3\end{array}$ & 3 & 1.13 & 5 \\
\hline \multirow[t]{5}{*}{ Environment } & E01 Unhygienic working environment & \multirow[t]{2}{*}{$7.55 \%$} & 4 & $\begin{array}{c}7.55 \\
\%\end{array}$ & - & - & & - & $\begin{array}{c}0.2 \\
3\end{array}$ & 3 & $\begin{array}{c}0.2 \\
3\end{array}$ & 3 & - & - & $\begin{array}{c}0.6 \\
8\end{array}$ & 9 & 1.13 & 5 \\
\hline & Total & & 53 & $100 \%$ & \multirow{2}{*}{\multicolumn{2}{|c|}{1.87}} & & & & & & & & & & & & \\
\hline & \multicolumn{4}{|l|}{ Absolute effectiveness } & & & 2.4 & & \multicolumn{2}{|c|}{2.66} & \multicolumn{2}{|c|}{2.94} & 0.3 & & \multicolumn{2}{|c|}{4.25} & & \\
\hline & \multicolumn{4}{|l|}{ Percent effectiveness } & \multicolumn{2}{|c|}{$12.86 \%$} & 16.7 & & \multicolumn{2}{|c|}{$18.31 \%$} & \multicolumn{2}{|c|}{$20.26 \%$} & 2.6 & & \multicolumn{2}{|c|}{$29.22 \%$} & & \\
\hline & \multicolumn{4}{|l|}{ Rank of priority } & \multicolumn{2}{|c|}{5} & 4 & & \multicolumn{2}{|c|}{3} & \multicolumn{2}{|c|}{2} & 6 & & \multicolumn{2}{|c|}{1} & & \\
\hline
\end{tabular}

